\title{
Sources and dosages of Nitrogen applied with urea coated with polymers in Marandu Palisade Grass
}

Fábio Janoni Carvalho ${ }^{1}$

Renata Bernardes Elias ${ }^{2}$

Adriane de Andrade Silva ${ }^{3}$

Thiago Souza Campos ${ }^{4}$

\begin{abstract}
Nitrogen is one of the most important nutrients for the production of forage grasses, and the most expensive one. The scope of this research was to evaluate the application of four sources of urea (conventional and coated with polymers) under different dosages, in mass production and nitrogen content and absorption from two cuts of Brachiaria brizantha cv. Marandu. The experiment was conducted at a greenhouse in a randomized block design. The fertilizers used were conventional urea, urea covered with a polymer layer, urea covered with sulfur and urea covered with a boron and copper compound. The dosages used were 30,60, 90 and $120 \mathrm{~kg} \mathrm{ha}^{-1}$ of nitrogen. Fresh and dry mass, root weight and nitrogen content from first and second harvest were evaluated. On the first harvest, there was no significant difference between the treatments for the variables analyzed. On the other hand, second harvest presented difference in fresh and dry mass and nitrogen content. Regression analyses showed a linear increase with all fertilizers used, but this growth was more accentuated for the polymerized fonts. All polymerized ureas allowed higher mass production for Marandu palisadegrass, at tillering and second cut. Foliar nitrogen availability of polymerized ureas did not differ from conventional urea, being recommended to reach pastures with higher quality and productions and to decrease nitrogen losses on the system.
\end{abstract}

Keywords: Brachiaria brizantha. Stabilization technologies. Sulfur polymer.

\section{Introduction}

Forage grasses represent plants of economic interest. Species from the gender Brachiaria are used in tropical countries as an option to pastures formation, because of the adaptability to different environmental conditions and facility in pasture's management (EUCLIDES et al., 2014). Marandu palisadegrass (Brachiaria brizantha cv. Marandu) is a perennial forage grass with cespitose growth habit, forming clumps up to one meter in diameter and tillers with 1.5 meter of height. It has horizontal, short, tough and curved rhizomes. It has deep roots, which help them to survive along dry periods (FONTES et al. , 2014).

1 Instituto Federal do Triângulo Mineiro - Campus Uberaba, Engenheiro Agrônomo. fabiojanoni@ufu.br. Rua João Batista Ribeiro, 4000 - Distrito Industrial II, Uberaba (MG), 38064-790.

2 Universidade Federal de Uberlândia, Instituto de Ciências Agrárias, graduada em Agronomia. renata25@ufu.br.

3 Universidade Federal de Uberlândia, Instituto de Ciências Agrárias, docente. adriane@iciag.ufu.br.

4 Universidade Federal de Uberlândia, Instituto de Ciências Agrárias. graduado em Agronomia. thiagocamposagr@gmail.com. 
Nitrogen is one of the most important nutrients for the production of forage grasses, and the most expensive one. With the correct application, it can increase the amount of protein and the quality of the graze (PINHEIRO et al., 2014). The lack of nitrogen in plant provokes the yellowing of older leaves, decreasing photosynthesis's rate. Therefore, low productivity rates can be the result of an inappropriate nitrogen fertilization (GÄRDENÄSA et al., 2011).

Methodologies optimizing the application and efficiency of nitrogenous fertilizers have increased in the last years. These techniques can increase efficiency according to two groups: slow release fertilizers (covered, encapsulated, insoluble or slowly soluble in water) and stabilized fertilizers (nitrification inhibitor or urease inhibitors). Slow release fertilizes can also be divided in two more groups: condensation compounds of urea (low solubility and slow release) and encapsulated or coated products (controlled release) (CANTARELLA, 2007).

In general, the choice of a nitrogenous fertilizer is based on the cost of nitrogen by unit and by the availability and efficiency from the source (KERING et al., 2011). The most sold fertilizers in the market are urea, ammonium nitrate and ammonium sulphate. Urea $\left[\mathrm{CO}\left(\mathrm{NH}_{2}\right)_{2}\right]$ is a solid granulated fertilizer with around $45 \%$ of nitrogen in the amide form. The advantages of urea are high concentration of nitrogen and low costs of fabrication, transportation, storage and application. However, it has disadvantages like higher hygroscopicity and volatility compared to other sources (HALVORSON; BARTOLO, 2014).

Technological efforts have been made to help the losses of ammonia from volatility, like coating urea with sulfur, new polymers and urease inhibitors (RUZEKA et al., 2014). Polymers are long chains of repeated structural units called monomers. Each polymer behaves differently to encapsulation, varying its release, which may be controlled by humidity or temperature (THAPA et al., 2015). The use of coated urea with polymers is a strategy that has been widely tested because encapsulated sources have a slow release compared to conventional soluble sources (FIGUEIREDO et al., 2012).

Considering the importance of nitrogen fertilization, as well as their topdressing for a quality pasture formation, this study had the aim of evaluate the effect from application of four sources of urea (conventional and coated with polymers) under different dosages, in mass production, root weight and nitrogen content at two cuts of $B$. brizantha cv. Marandu.

\section{Material and methods}

The study was conducted in a greenhouse of Universidade Federal de Uberlândia, at $18.885^{\circ} \mathrm{S}$ and $48.259^{\circ} \mathrm{W}$. The experiment design was a randomized block design (RBD) in a $4 \times 4+1$ factorial (fertilizers $x$ dosages) and three blocks. The fertilizers used were conventional urea, urea covered with a polymer layer, urea covered with sulfur, and urea covered with a boron and copper compound. All the fertilizers had the same amount of nitrogen (45\% of $\mathrm{N}$ ). The dosages used were 30;60; 90 and $120 \mathrm{~kg} \mathrm{ha}^{-1}$ of nitrogen at planting and coverage. An additional control without any application of nitrogen was added to the experiment.

The soil used was an Oxisol, medium texture, compound by $423 \mathrm{~g} \mathrm{~kg}^{-1}$ of gravel, $205 \mathrm{~g} \mathrm{~kg}^{-1}$ of fine sand, $36 \mathrm{~g} \mathrm{~kg}^{-1}$ of silt and $336 \mathrm{~g} \mathrm{~kg}^{-1}$ of clay. The $\mathrm{pH}$ in water was 5.8; content of available phosphorus of $1.7 \mathrm{mg} \mathrm{dm}^{-3}$; available potassium of $21 \mathrm{mg} \mathrm{dm}^{-3}$; sulfur of $9 \mathrm{mg} \mathrm{dm}^{-3}$; organic matter of $21.0 \mathrm{mg} \mathrm{dm}^{-3}$ and saturation of bases of $75 \%$. It was performed a correction with single superphosphate in soil, equivalent to $120 \mathrm{~kg} \mathrm{ha}^{-1}$ before sowing. 
Sowing was conducted with 25 seeds of $B$. brizantha cv. Marandu per pot. Each pot contained $0.3 \mathrm{~kg} \mathrm{dm}^{-3}$ of soil and was drilled in the bottom to remove water excess. The thinning was made twenty days after sowing, letting 4 plants per pot. A cut of $10 \mathrm{~cm}$ height was held in 30 days after sowing. Topdressing was superficial without incorporation, after the first cut. Irrigation was carried out in an interval of two days, throughout the experiment with the help of tensiometers. The second cut was held at 60 days after sowing.

After cut, the leaf blades and other components were weighed in a precision balance to calculate the fresh mass production. Then, they were dried in a kiln at $65^{\circ} \mathrm{C}$ and removed when it got constant mass. After drying, the samples were weighed for dry mass production calculation (SILVA, 2009). A leaf analysis was also conducted in order to determine the nitrogen content with two newly expanded leaves of the plant, according to Kuhinara, Maeda e Alvarez (2005) methodology. At the end of the experiment (second cut), the plants were removed, separating vegetative portion from the roots, and then they were weighted separately. The leaves and roots were also dried in a kiln at 65 ${ }^{\circ} \mathrm{C}$ for dry mass calculation.

For normality of residuals and homogeneity of variances Shapiro Wilk and Levene's tests were performed, respectively ( $p$-value $=0.05$ ). Analysis of variance (ANOVA) was performed with 0.01 of significance. In case of significant difference, Tukey's test was used to compare the means at 0.05 of significance. Dunnett's test was performed to compare treatments with the additional control. Regression analysis was performed for the dosages. R software was used to run the statistics.

\section{Results and discussion}

On first cut, there was no significant difference between the treatments for the variables analyzed (Table 1). The fonts of urea did not differ from the control either, just for nitrogen content. For initial development of $B$. brizantha, there was no interference from the polymers or the dosage of urea. However, the treatments differed from the control in nitrogen content, showing the importance of a correct adubation for the plants. Alexandrino et al. (2004) demonstrated how important nitrogen is to leaf appearance and elongation rate in $B$. brizantha.

Table 1. Analyses of variance for fresh and dry mass, nitrogen content and root weight of two cuts of $B$. brizantha submitted to dosages of nitrogen fertilizers.

\begin{tabular}{|c|c|c|c|c|c|c|c|c|}
\hline \multirow{3}{*}{$\begin{array}{l}\text { Source of } \\
\text { variation }\end{array}$} & & \multicolumn{2}{|c|}{ Green mass } & \multicolumn{2}{|c|}{ Dry mass } & \multicolumn{2}{|c|}{ Nitrogen content } & \multirow{2}{*}{$\begin{array}{c}\text { Root } \\
\text { weight }\end{array}$} \\
\hline & \multirow{2}{*}{$d f$} & $1^{\text {st }}$ cut & $2^{\text {nd }}$ cut & $1^{\text {st }}$ cut & $2^{\text {nd }}$ cut & $1^{\text {st }}$ cut & $2^{\text {nd }} c u t$ & \\
\hline & & \multicolumn{7}{|c|}{ Mean square } \\
\hline Fertilizer & 3 & $0.77^{\mathrm{ns}}$ & $32.77^{\mathrm{ns}}$ & $0.91^{\mathrm{ns}}$ & $2.84^{\mathrm{ns}}$ & $37.39^{\text {ns }}$ & $0.05^{\text {ns }}$ & $480.27^{\mathrm{ns}}$ \\
\hline Dosage & 3 & $1.99^{\text {ns }}$ & $2.77^{\mathrm{ns}}$ & $5.52^{\mathrm{ns}}$ & $2.54^{\mathrm{ns}}$ & $21.02^{\mathrm{ns}}$ & $0.83^{* *}$ & $304.08^{\text {ns }}$ \\
\hline Interaction & 15 & $1.99^{\text {ns }}$ & $51.73^{* *}$ & $13.87^{\mathrm{ns}}$ & $12.01^{* *}$ & $34.28^{\text {ns }}$ & $0.09^{\text {ns }}$ & $156.70^{\text {ns }}$ \\
\hline $\begin{array}{c}\text { Factors x } \\
\text { Control }\end{array}$ & 1 & $0.18^{\text {ns }}$ & $1027.78^{\star *}$ & $12.01^{\mathrm{ns}}$ & $31.38^{* *}$ & $37.77^{* *}$ & $24.45^{\star *}$ & $218.43^{\text {ns }}$ \\
\hline Residual & 32 & 0.87 & 14.79 & 7.455 & 1.813 & 24.88 & 0.08 & 138.43 \\
\hline CV (\%) & & 8.21 & 14.94 & 29.95 & 28.56 & 26.20 & 7.33 & 34.00 \\
\hline
\end{tabular}

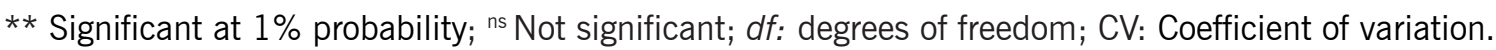

Source: Elaborated by the authors (2017). 
On the other hand, second cut presented difference in fresh and dry mass. Dunnett's test showed difference between all treatments compared to control, which was expected (Table 2). Nitrogen fertilization is a strategy that allows increase of volume density of forage, and especially leaves production, due more leaf emergence and elongation, elevating dry mass production (FRAME et al., 2013). Despite increase of mass with the treatments, no difference was detected in root weight. Radicular system of Brachiaria is more affected by potassium and phosphorus than nitrogen (COSTA et al., 2009).

Table 2. Fresh and dry mass from second cut of $B$. brizantha cv. Marandu under application of different polymerized fertilizers.

\begin{tabular}{ccc}
\hline Fertilizer & $\begin{array}{c}\text { Fresh mass } \\
\left(\text { g pot }^{-1}\right)\end{array}$ & $\begin{array}{c}\text { Dry mass } \\
\left(\text { g pot }^{-1}\right)\end{array}$ \\
\hline Conventional urea & $23.90 \mathrm{~b}$ & $6.95 \mathrm{~b}$ \\
Covered with polymer & $29.00 \mathrm{a}$ & $13.35 \mathrm{a}$ \\
Covered with sulfur & $29.09 \mathrm{a}$ & $15.20 \mathrm{a}$ \\
Covered with boron and copper & $28.92 \mathrm{a}$ & $14.97 \mathrm{a}$ \\
No urea & $8.32^{*}$ & $4.32^{*}$ \\
\hline
\end{tabular}

Means, followed by the same small letters in columns do not differ significantly by Tukey's test ( $p$-value $\leq 0.05$ ). ${ }^{*}$ Control differs from treatments by Dunnett's test ( $p$-value $\leq 0.05$ ).

Source: Elaborated by the authors (2017).

Independently of the type of polymerized urea, Tukey's test revealed increase on plant mass when compared to conventional urea, showing that when urea is revested, the chances of losses for ambience are decreased, confirming the remarks of Ruzeka et al. (2014). Regression analyses (Figure 1) adjusted a linear increase for all fertilizers used; however, this rise was more accentuated for the polymerized fonts. Other authors found the same effects with the rise of urea dosages in Marandu palisadegrass (PRIMAVESI et al., 2006; COSTA et al., 2009). The content of mass in coated ureas duplicated from the smallest to the highest dosage used, and the high coefficients of determination from the equations confirm how responsive Marandu palisadegrass was to the rise of nitrogen availability. Even if conventional urea had raised fresh mass content too, it was not observed difference for dry mass content.

For the first cut, the content of nitrogen in all treatments were statistically equal $\left(17.15 \mathrm{~g} \mathrm{~kg}^{-1}\right)$ differing only from the control $\left(9.37 \mathrm{~g} \mathrm{~kg}^{-1}\right)$. All coated ureas had the same behavior than conventional urea for nitrogen foliar assimilation. That information proved that these fonts are well absorbed by the plant, and their slowly liberation did not affect nitrogen availability for plant on current planting. The most worrying scenario for coated ureas is when their slow liberation do not provide the correct nitrogen quantity (SILVA et al. , 2012). Besides that, all coated ureas provided more mass production, essential for a good pasture. Farruggia et al. (2014) revealed nitrogen content and mass production are the most important attributes for quality pasture.

Second cut showed the same difference, but dosage increase adjusted to a linear regression (Figure 2). Same linear positive effect was observed by Fagundes et al. (2006) with Brachiaria decumbens. However, some authors report having found that Marandu palisadegrass was sensible to higher increase of nitrogen (ALEXANDRINO et al., 2004, 2010), that was not observed in our study nonetheless. 
Figure 1. Fresh and dry mass of $B$. brizantha cv. Marandu submitted to different rates four types of urea $(-\cdots$ conventional urea; - urea covered with a polymer layer; - - urea covered with sulfur; - - urea covered with a boron and copper compound).
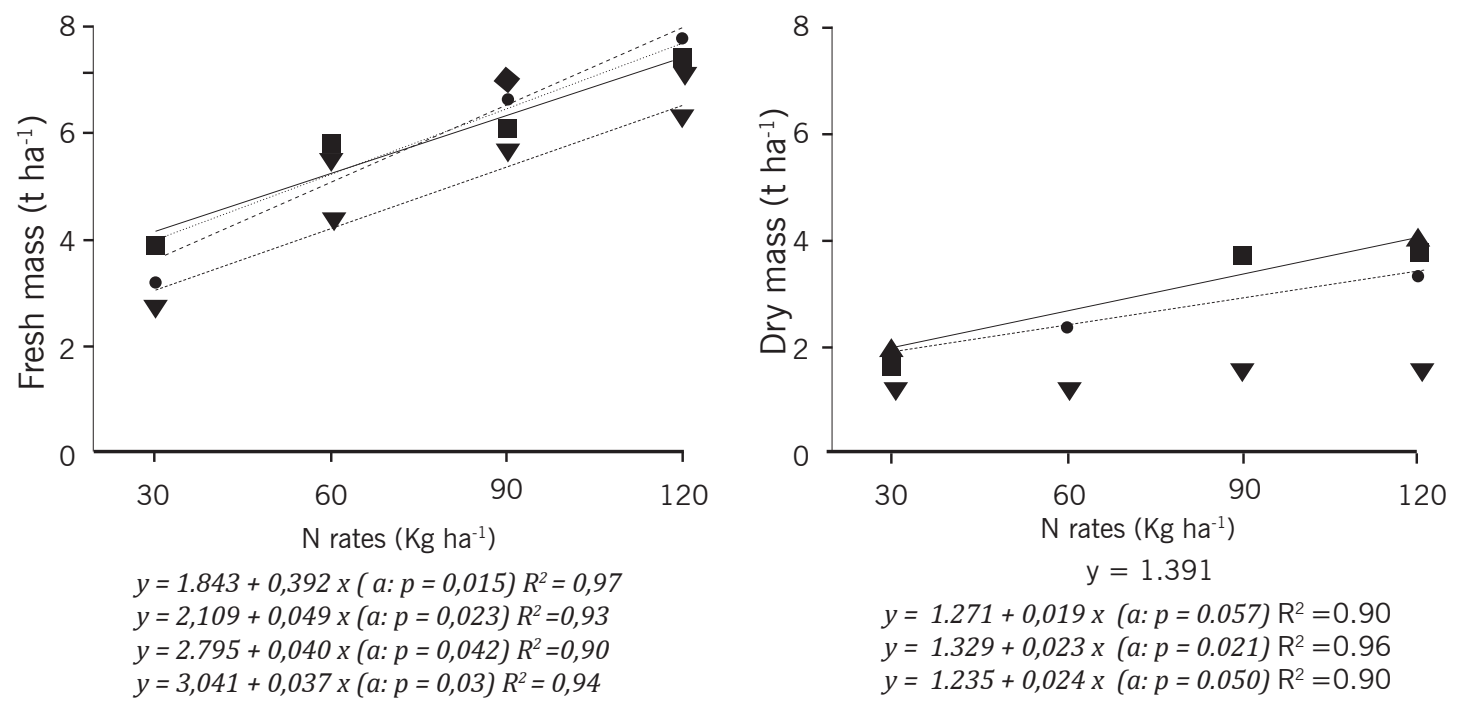

Source: Elaborated by the authors (2017).

Figure 2. Foliar nitrogen content from second cut of $B$. brizantha cv. Marandu submitted to dosages of urea fertilizers.

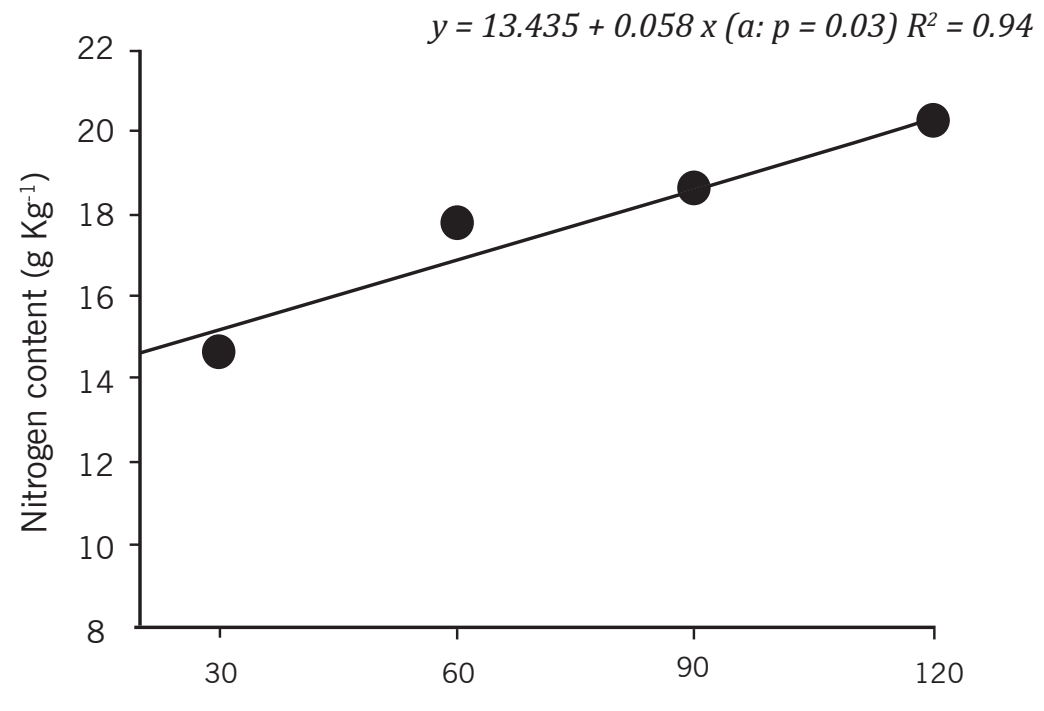

Source: Elaborated by the authors (2017). $\quad$ N rates $\left(\mathrm{Kg} \mathrm{ha}^{-1}\right)$ 
Polymerized ureas were never used on Marandu palisadegrass, and this work shows that they have promising ways to improve the pasture quality throughout the year. Recent works of Queiroz et al. (2011) and Silva et al. (2012) showed same results with conventional urea and polymerized for the development of Zea mays; however polymerized urea was still recommended because of its long term effects.

\section{Conclusion}

All polymerized ureas allowed higher mass production for Marandu palisadegrass at tillering and second cut. Foliar nitrogen availability of polymerized ureas did not differ from conventional urea, being recommended to reach pastures with higher quality and productions and to decrease nitrogen losses on the system. Future studies need to be performed to evaluate the effects on a Marandu palisadegrass pasture all year long.

\section{Fontes e doses de nitrogênio aplicadas com ureia revestida por polímeros no capim Marandu}

\section{Resumo}

O nitrogênio é um dos nutrientes mais importantes para a produção de gramíneas forrageiras e também o mais caro. Objetivou-se avaliar a aplicação de quatro fontes e quatro doses de ureia na produção de forragem e teor de nitrogênio na Brachiaria brizantha cv. Marandu. O experimento foi conduzido em casa de vegetação. Os fertilizantes utilizados foram ureia convencional, ureia revestida por camada de polímero, ureia revestida com enxofre e ureia revestida com composto de boro e cobre. As doses utilizadas foram 30, 60, 90 e $120 \mathrm{~kg} \mathrm{ha}^{-1}$ de nitrogênio. A massa verde e seca, peso de raízes e teor de nitrogênio no primeiro e segundo cortes foram avaliados. No primeiro corte, não houve diferença entre os tratamentos. Por outro lado, o segundo corte apresentou diferença no teor de nitrogênio e na produção de forragem. $O$ aumento linear ocorreu em todos os fertilizantes utilizados, sendo mais acentuado nas fontes revestidas. Ureias polimerizadas permitiram maior produção de massa para o capim Marandu, especialmente para o perfilhamento e para o segundo corte. O conteúdo de nitrogênio foliar das ureias polimerizadas não diferiu da ureia convencional, sendo recomendadas para obtenção de pastagens com maior qualidade e produção além de auxiliar na redução de perdas de nitrogênio no sistema.

Palavras-chave: Brachiaria brizantha. Tecnologias de estabilização. Polímero de enxofre. 


\section{References}

ALEXANDRINO, E.; NASCIMENTO JÚNIOR, D.; MOSQUIN, P. R.; REGAZZI, A. J.; ROCHA, F. C. Características Morfogênicas e Estruturais na Rebrotação da Brachiaria brizantha cv. Marandu Submetida a Três Doses de Nitrogênio. Revista Brasileira de Zootecnia, v. 33, n. 6, p. 1372-1379, 2004. Disponível em: <http://www.scielo.br/pdf/rbz/v33n6/a03v33n6 > . Acesso em: 06 set. 2017.

ALEXANDRINO, E.; VAZ, R. G. M. V.; SANTOS, A. C. Características da Brachiaria brizantha cv. Marandu durante o seu estabelecimento submetida a diferentes doses de nitrogênio. Bioscience Journal, Uberlândia, v. 26, n. 6, p. 886-893, 2010. Disponível em: <http://www.seer.ufu.br/index. php/biosciencejournal/article/view/7226/6608 > . Acesso em: 06 set. 2017.

CANTARELLA, H. Nitrogênio. In: NOVAIS, R. F. Fertilidade do solo. Viçosa: SBCS, 2007. p. 375470.

COSTA, K. A. P.; OLIVEIRA, I. P.; FAQUIN, V.; SILVA, G. P.; SEVERIANO, E. C. Produção de massa seca e nutrição nitrogenada de cultivares de Brachiaria brizantha (A. Rich) Stapf sob doses de nitrogênio. Ciência e Agrotecnologia, Lavras, v. 33, n. 6, p. 1578-1585, 2009. Disponível em: <doi: 10.1590/S1413-70542009000600017>. Acesso em: 06 set. 2017.

EUCLIDES, V. P. B.; MONTAGNER, D. B.; BARBOSA, R. A.; NANTES, N. N. Manejo de pastejo de cultivares de Brachiaria brizantha (Hochst) Stapf e de Panicum maximum Jacq. Revista Ceres, Viçosa, v. 61, p. 808-818, 2014. Disponível em: <doi: 10.1590/0034-737x201461000006 >. Acesso em: 06 set. 2017.

FARRUGGIA, A.; POMIES, D.; COPPA, M.; FERLAY, A.; VERDIER-METZ, I.; MORVAN, A. L.; BETHIER, A.; POMPANON, F.; TROQUIER, O.; MARTIN, B. Animal performances, pasture biodiversity and dairy product quality: How it works in contrasted mountain grazing systems. Agriculture, Ecosystems \& Environment, v. 185, p. 231-244, 2014. Disponível em: <doi: 10.1016/j.agee.2014.01.001>. Acesso em: 06 set. 2017.

FAGUNDES, J. L.; FONSECA, D. M.; MISTURA, C.; MORAIS, R. V.; VITOR, C. M. T.; GOMIDE, J. A.; NASCIMENTO JUNIOR, D.; CASAGRANDE, D. R.; COSTA, L. T. Características morfogênicas e estruturais do capim-braquiária em pastagem adubada com nitrogênio avaliadas nas quatro estações do ano. Revista Brasileira de Zootecnia, Viçosa, v. 35, n. 1, p. 21-29, 2006. Disponível em: < http:// www.scielo.br/pdf/\%0D/rbz/v35n1/28338.pdf>. Acesso em: 06 set. 2017.

FIGUEIREDO, C. C.; BARBOSA, D. V.; OLIVEIRA, A. S.; FAGIOLI, M.; SATO, J. H. Adubo fosfatado revestido com polímero e calagem na produção e parâmetros morfológicos de milho. Revista Ciência Agronômica, Ceará, v. 43, n. 3, p. 446-452, 2012. Disponível em: < http://www.redalyc.org/ html/1953/195322286005>. Acesso em: 06 set. 2017.

FONTES, J. G. G.; FAGUNDES, J. L.; BACKES, A. A.; BARBOSA, L. T.; CERQUEIRA, E. S. A.; SILVA, L. M.; MORAIS, J. A.; VIEIRA, J. S. Acúmulo de massa seca em cultivares de Brachiaria brizantha submetida a intensidades de desfolhação. Semina, Londrina, v. 35, n. 3, p. 1425-1438, 2014. Disponível em: <doi: 10.5433/1679-0359.2014v35n3p1425>. Acesso em: 06 set. 2017. 
FRAME, W. H.; ALLEY, M. M.; THOMASON, W.; WHITEHURST, G. B.; WHITEHURST, B. M.; CAMPBELL, R. Agronomic Evaluation of Coated Urea to Reduce Ammonia Volatilization From Side-Dress Applications to Corn. Crop Management, v. 12, n. 1, 2013. Disponível em: <doi:10.1094/CM2013-0117-01-RS>. Acesso em: 06 set. 2017.

GÄRDENÄSA, A. I.; ÅGRENB, G. I.; BIRDC, J. A.; CLARHOLMD, M.; HALLINE, S.; INESONF, P.; KÄTTERERG, T.; KNICKERH, H.; NILSSONG, S. I.; NÄSHOLMI, T.; OGLEJ, S.; PAUSTIANJ, K.; PERSSONB, T.; STENDAHLA, J. Knowledge gaps in soil carbon and nitrogen interactions - From molecular to global scale. Soil Biology and Biochemistry, v. 4, n. 4, p. 702-717, 2011. Disponível em: <doi: 10.1016/j.soilbio.2010.04.006 >. Acesso em: 06 set. 2017.

HALVORSON, A. D.; BARTOLO, M. E. Nitrogen Source and Rate Effects on Irrigated Corn Yields and Nitrogen-Use Efficiency. Agronomy Journal, v. 106, n. 2, p. 681-693, 2014. Disponível em: $<$ doi:10.2134/agronj2013.0001 >. Acesso em: 06 set. 2017.

KERING, M. K.; BUTLER, T. J.; BIERMACHER, J. T.; GURETZKY, J. A. Biomass Yield and Nutrient Removal Rates of Perennial Grasses under Nitrogen Fertilization. BioEnergy Research, v. 5, n. 1, p. 61-70, 2011. Disponível em: <doi: 10.1007/s12155-011-9167-x>. Acesso em: 06 set. 2017.

KUHINARA, C. H.; MAEDA, S.; ALVAREZ, V. H. V. Interpretação de resultados de Análise Foliar. Dourados: Embrapa Florestas, 2005.

PINHEIRO, A. A.; CECATO, U.; LINS, T. O. D. J.; BELONI, T.; PIOTTO, V. C.; RIBEIRO, O. L. Produção e valor nutritivo da forragem, e desempenho de bovinos Nelore em pastagem de capim-Tanzânia adubado com nitrogênio ou consorciado com estilosantes Campo Grande. Semina: Ciências Agrárias, Londrina, v. 35, n. 4, p. 2147-2158, 2014. Disponível em: <doi: 10.5433/1679-0359.2014v35 n4p2147>. Acesso em: 06 set. 2017.

PRIMAVESI, A. C.; PRIMAVESI, O.; CORRÊA, L. A.; SILVA, A. G.; CANTARELLA, H. Nutrientes na fitomassa de capim-marandu em função de fontes e doses de nitrogênio. Ciência e Agrotecnologia, Lavras, v. 30, n. 3, p. 562-568, 2006. Disponível em: < https://www.alice.cnptia.embrapa.br/alice/ bitstream/doc/47424/1/PROCl2006.00020.pdf > . Acesso em: 06 set. 2017.

QUEIROZ, A.; SOUZA, C. H. E.; MACHADO, V. J.; LANA, R. M. Q.; KORNDORFER, G. H.; SILVA, A. A. Avaliação de diferentes fontes e doses de nitrogênio na adubação da cultura do milho (Zea mays L.). Revista Brasileira de Milho e Sorgo, v. 10, n. 3, p. 257-266, 2011. Disponível em: <doi: 1 10.18512/1980-6477/rbms.v10n3p257-266 >. Acesso em: 06 set. 2017.

RUZEKA, L.; RUZKOVÁB, M.; BECKAC, D.; VORISEKA, K.; SIMKAC, J. Effects of Conventional and Stabilized Urea Fertilizers on Soil Biological Status. Communications in Soil Science and Plant Analysis, v. 45, n. 17, p. 2363-2372, 2014. Disponível em: <doi: 10.1080/00103624.2014.912294>. Acesso em: 06 set. 2017.

SILVA, F. C. D. S. Manual de análises químicas de solos, plantas e fertilizantes. Rio de Janeiro: Embrapa Solos, 2009. 
SILVA, A. A.; SILVA, T. S.; VASCONCELOS, A. C. P.; LANA R. M. Q. Aplicação de diferentes fontes de ureia de liberação gradual na cultura do milho. Bioscience Journal, Uberlândia, v. 28, n. 1, p. 104-111, 2012. Disponível em: <http://www.seer.ufu.br/index.php/biosciencejournal/article/ view/13242/8354>. Acesso em: 06 set. 2017.

THAPA, R.; CHATTERJEEA, A.; JOHNSONB, J. M. F.; AWALEA, R. Stabilized Nitrogen Fertilizers and Application Rate Influence Nitrogen Losses under Rainfed Spring Wheat. Agronomy Journal, v. 15, n. 1, p. 1-12, 2015. Disponível em: <doi: 10.2134/agronj15.0081 >. Acesso em: 06 set. 2017.

\section{Histórico editorial:}

Submetido em: 17/03/2017

Aceito em: 15/09/2017

Como citar:

ABNT

CARVALHO, F. J.; ELIAS, R. B.; SILVA, A. A.; CAMPOS, T. S. Sources and dosages of Nitrogen applied with urea coated with polymers in Marandu Palisade Grass. Revista Agrogeoambiental. Pouso Alegre, v. 10, n. 3, p. 135-143, jul./set. DOI: http://dx.doi.org/10.18406/2316-1817v10n320181189

APA

CARVALHO, F. J., ELIAS, R. B., SILVA, A. A. \& CAMPOS, T. S. (2018). Sources and dosages of Nitrogen applied with urea coated with polymers in Marandu Palisade Grass. Revista Agrogeoambiental, 10 (3), 135-143. DOI: http://dx.doi.org/10.18406/2316-1817v10n320181189

$\underline{\text { ISO }}$

CARVALHO, F. J.; ELIAS, R. B.; SILVA, A. A. e CAMPOS, T. S. Sources and dosages of Nitrogen applied with urea coated with polymers in Marandu Palisade Grass. Revista Agrogeoambiental, 2018, vol. 10, n. 3, pp. 135-143. Eissn 2316-1817. DOI: http://dx.doi.org/10.18406/2316-1817v10n320181189

\section{VANCOUVER}

Carvalho FJ, Elias RB, Silva AA, Campos TS. Sources and dosages of Nitrogen applied with urea coated with polymers in Marandu Palisade Grass. Rev agrogeoambiental. 2018 jul/set; 10(3): 135-143. DOI: http://dx.doi.org/10.18406/2316-1817v10n320181189 


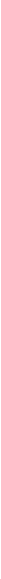

